Relations industrielles

Industrial Relations

\title{
Reforms in Structure and Unionism
}

\section{Marcel Clément}

Volume 4, numéro 3, novembre 1948

URI : https://id.erudit.org/iderudit/1023447ar

DOI : https://doi.org/10.7202/1023447ar

Aller au sommaire du numéro

Éditeur(s)

Département des relations industrielles de l’Université Laval

ISSN

0034-379X (imprimé)

1703-8138 (numérique)

Découvrir la revue

Citer cet article

Clément, M. (1948). Reforms in Structure and Unionism. Relations industrielles / Industrial Relations, 4(3), 21-23. https://doi.org/10.7202/1023447ar

Tous droits réservés @ Département des relations industrielles de l’Université Laval, 1948
Ce document est protégé par la loi sur le droit d'auteur. L'utilisation des services d'Érudit (y compris la reproduction) est assujettie à sa politique d'utilisation que vous pouvez consulter en ligne.

https://apropos.erudit.org/fr/usagers/politique-dutilisation/ 


\section{Bulletin des relations industrielles}

Volume 4, number 3

QUEBEC

November 1948

\section{Published by the \\ Department of Industrial Relations, Faculty of Social Sciences, Laval University. \\ Georges-Henri Lévesque, o.p., Dean Gerard Tremblay, Director GÉrard Dion, Assistant-Director Jean GaGne, Secretary \\ Charles Bellanger, Administrator}

The Bulletin is published monthly, September to June inclusively (ten issues a year). Annual subscription: Canada: $\$ 1.50$; Foreign: $\$ 2.00$. Single copies: twenty-five cents.

Publication indexed in the "Canadian Index".

All correspondance must be addressed to the Literary Editor GÉrard Dion

2, University Street, Quebec.

Bulletin des relations industrielles

Volume 4, number 3 November 1948

Contents

Reforms in Structure

and Unionism

Marcel ClÉment

Labour leaders in study session

Marcel DE LA SABLONNière

How the D.S.B. Cost-of-Living

Index is calculated

Recreation and Labour Relations

Louise Dumais.

The new Federal Labour

Relations Act

Denys Dion.

\section{Contributors}

Bancroft, (Mrs.) M T., Translator of the Bulletin.

Clément, Marcel, Licencié ès lettres, diplômé d'études supérieures en philosophie (Sorbonne), licencié en droit, diplômé d'études supérieures d'économie politique (Faculté de droit de Paris), Professor, Faculty of Social Sciences of Laval University.

de LA Sablonnière, Marcel, S.J., Professor, College Ste-Marie, Montreal.

DumaIs, Louise, M.Sc.S., (Social Work), Secretary, Section d'étude des loisirs, Conseil Central des Oeuvres de Québec (Welfare Council), Professor, School of Social Work, in charge of training courses for recreation leaders, Faculty of Social Sciences, Laval University.

Dion, Denys, Lawyer, Quebec Bar.

Authorized as second class mail

Post-office Department, Ottawa, Canada.

\section{REFORMS IN STRUCTURE AND UNIONISM}

\author{
Marcel Clément
}

Now when, on all sides, we find the problem of enterprise reform foremost in the minds of men, it is possible to establish two tendencies in the unions. On one hand, a large number of officials (this was noticeable at the workers meeting of the "Congrès des relations industrielles») are favourable to reform. On the other hand, certain men, and these not the least fine and intelligent, indicated their fear that an extension of the structural reform movement in enterprise would be injurious to the development of unionism. Faced with such a state of mind it is not enough to assert. We must investigate carefully. The problem is actually too serious, and concerns too deeply our economic and social future to permit us to content ourselves with superficial opinions. The problem presents itself under two aspects - on the plane of principles and on the practical level of action.

\section{I}

Is there, on the plane of the fundamental principles which govern them, opposition or «composition» between unionism and the enterprises of the community?

What is unionism? Etymologically the word come from the Latin « unio » - unity. (unus - one) Actually it, like its French counterpart «syndicalisme» of Greek origin, suggests a community, at one in its interests, acting with a view of obtaining justice. Here then is an aim positive to a degree.

The general aims of those unions subjected to Christian influences - such aims as the pontifical texts establish, for example - only extend and broaden this fundamental desire for justice, by adding to it the concept of love and charity.

An excerpt from the letter of the «Sacré-Congrégation du Concile » dated June 5, 1929 reads, «We must make it a universal and constant rule to organize and govern the corporations (according to the context - syndicated associations or unions) so that they will furnish to each of their members 
the appropriate means to attain by the easiest and shortest way the ends which they propose for themselves and which consist in the greatest possible increase in the well-being of the body, mind and fortune. But it is evident that we must aim before all at the principal object which is moral and religious perfection. ${ }^{1}$

It follows that the physical and cultural growth of the workers (necessarily conditioned by their income) is the purpose of union action. To attain its aim the union has a choice of means and it is in its interest to choose the shortest and the easiest one.

If such is the aim of Christian unionism, we ask ourselves what is the aim pursued by structural reforms within the enterprise. Without going back at great length, let us recall that the different methods all call on the workers and employers « to share in some manner in the ownership of the enterprise, in its management and in the profits which it brings. ${ }^{2}$ It is not all doubtful that this participation advocated by the Encyclical «Quadragesimo Anno », far from contradicting the letter of 1929, two years later indicated a sure method of «increasing the well-being of the body, mind and fortune. »

One can then affirm, without complicated or subtle arguments, that Christian unionism and structural reforms are two means to but a single end - the harmonious development, within our modern economic society, of the human personality.

\section{II}

The questions of principle once regulated, we come up against the practical problem itself. In order to understand all its difficulties, it is advisable to recall in broad outline what has been the evolution of unionism since its origin. If, as we have stressed, the end pursued by the unions is an eminently positive one, it is necessary to state, nevertheless that, because of the obstacles encountered, it is mainly under a negative form that action has developed. The concerted action of Labour with a view to social justice should, ideally, encounter a favourable reception. Thus, in circles differing fundamentally from those of laissez-faire «liberalism », it would be possible to see develop a unionism not of bargaining but of co-operation. The form of the organizations and

(1) Chevalier et Marmy. No. 456, (Letter of the "SacréCongrégation" to Mgr. Lienart).

(2) Chevalier et Marmy. No. 511, in fine, (Quadragesimo Anno). their aim would remain the same. But their attitude confronting their employers would be modified. Instead of closed unions directed towards crushing opposition, we would have open unions whose role of discussion and debate would be founded on a technical knowledge of human and social needs and not on complaints of an aggressive nature.

Historically, we repeat, it has not been so. It was in violation of the laws of the laissez-faire regime that the workers attempted to unionize more than a hundred years ago. Even to-day, when the law of the land not only authorizes but even favours the growth of union organizations and urges them distinctly to proceed from the stage of bargaining to that of employer-employee co-operation, we must acknowledge that this evolution is hindered and more or less retarded by the mutual distrust which animates employers faced with union action and unions faced with the employers' attitude. Thus it is that the double association of employers and workers and its natural broadening into unity in the parity committees has not yet reached its full Christian value. We live, on the social plane, in an unhappy time of transition between a unionism of bargaining and one of co-operation - between war and peace. If we take this fact into account we find that unionism is at the cross-roads. If it ceases to make demands it risks being imposed upon. If it refuses to be constructive in a spirit of co-operation it betrays its mission. In practice it can be said that up till now, owing to the persistance of the «liberal» spirit, the bargaining has a more important place than co-operation. Co-operation here being defined as the active sharing of the workers in economic life after a social and cultural training received in their union!

There is the background against which operates the problem of reform in structure. And all the difficulties which are real, come from these conditions.

We have already observed that it is, in principle, the employer who should take the initiative in these reforms. Their success would regulate in a relatively automatic fashion, the problem not of basic wages but of their social complement. Before such a perspective does not union action risk seeing its object disappear? And, on the other hand, is not the temptation very strong for the employer to delay legitimate raises in the basic wage by referring to the profit-sharing? With a weakened union control this might result in a distressing set-back. Such is the problem. To our way of thinking to state it is to solve it. 
As a matter of fact, all these dangers exist only in the measure that fear of them inspires an attitude of passivity in the officials. But, this is neither necessary nor inevitable. If the labour world, while respecting the freedom of the employer's initiative, makes sufficiently understood that it would welcome his efforts with favour, the employer's gesture would present itself as an answer which far from harming the unions would re-unite them in a common aspiration towards social peace. When there are wage demands and employers' compromises we are in a «liberal» regime. But, if the Labour world sees an aspiration which is dear to it freely satisfied by employers who are hoping to realize a community within the enterprise, unionism is then complete in its role of social progress - and we are in a Christian regime. This was well explained by Mr. Gérard Picard, President of C.C.C.L. (C.T.C.C.) in his inaugural speech at the Congress of 1948.

The undertaking of the study of reforms by the unions usually leads to their becoming the organization in the enterprise which carries out these ideas in co-operation with the direction. If the community of profit-sharing, sooner or later, calls on the committees of the enterprise it is evi- dent that only the union representation can give these latter a basis sufficiently competent and sufficiently mature. In such a case it is union watchfulness which permits the avoidance of mistakes between basic wage adjustments and the sharing of profits.

Thus the dangers of enterprise reform are serious only when the unionism is passive or hostile. With a progressive unionism reform can be the providential means of advancing definitely, in enterprise after enterprise, from bargaining to co-operation, from systematic opposition to systematic «composition», from laissez-faire enterprise to free entreprise. The unimpeded character of the employer's efforts and his outlook in matters of employer-employee co-operation virtually determines for those who wish to «construct a social edifice on the unshakeable centre of gravity of the Divine Law ${ }^{3}$ which of these reforms are the measures most apt to dispel the worker's mistrust which, in the last analysis, is the measure of managements' distrust. The Golden Rule here should serve as guiding principle. Love knows not fear.

(3) Pope Pius XII, Christmas Message 1942.

\title{
LABOUR LEADERS IN STUDY SESSION
}

\author{
MARCEL dE LA SABLonNière
}

Each week-end of last August saw the arrival at the Island of St. Ignace, from the principal industrial centres of the Province, of some forty or so labour leaders - official delegates from their respective unions.

The atmosphere. - From Friday evening to Sunday evening, at the conferences as in the discussion groups, in the casual conversations as in the evening forums, there was always the same sympathetic atmosphere whose perfect simplicity and frank cordiality, as back-ground for the relations of the workers among themselves, contributed to the attraction and success of the conferences.

Felt by everyone was a great desire to better understand the solutions to those economic and social problems presented by the present day condition of the enterprise and by the alarming rise in the cost of living with its distressing repercussions on the subsistence level of the working-man's family.

The subject for the year. - The labour leaders had chosen "The Canadian Worker Face to Face with Inflation» as subject. «We have not here», observed Father Jacques Cousineau, s.j., originator of these union summer sessions, « a question properly of union interest since, if you will, it does not concern the worker as producer in his relations with his employers. It is the consumer who is concerned here, that is, the worker who must provide shelter and food for himself as well as balance a budget. »

Group discussions. - The lectures finished - there were two a day - those present dispersed in groups of five or six to the grateful shade of the 